\title{
ERRATUM
}

\section{That Which Belongs to All: Khipus, COMMUNITY, AND INDIGENOUS LEGAL ACTIVISM IN THE EARLY COLONIAL ANDES-ERRATUM}

José Carlos de la Puente Luna

doi: 10.1017/tam.2014.4, Published by Cambridge University Press 20 February, 2014.

The original publication of this article contained an incorrect email address for the author. The correct address is reproduced below.

$<j d 65 @ t x s t a t e . e d u>$

The publisher regrets the error.

\section{REFERENCE}

José Carlos de la Puente Luna (2014). That Which Belongs to All: Khipus, Community, and Indigenous Legal Activism in the Early Colonial Andes. The Americas, 72(1), pp. 19-54. doi: $10.1017 / \operatorname{tam} .2014 .4$ 